\title{
Relationship Between Leadership Styles of Sports Administrators and Orgranisational Development in Ilorin Metropolis, Nigeria
}

\author{
Issa Yaqub Ajeigbe ${ }^{1 *}$, Abdulraheem Yunus Owolabi², Semiu \\ Alasinrin $^{3}$ \\ ${ }_{1 * 3}$ Department of Human Kinetics and Health Education, Faculty of Education, Kwara State \\ University, Malete, Nigeria \\ 2Department of Human Kinetics and Health Education, University of Ilorin, Nigeria
}

\begin{abstract}
Article History:
Received: 13 March 2021

Accepted: 25 April 2021

Published: 26 April 2021
\end{abstract}

Keywords:

Leadership Style; Sports Administrator; Organization

Performance

\begin{abstract}
The research employs descriptive survey design of correlation type which is very important as the study tries to find out the relationship between leadership styles of sports administrators and organization performance in Ilorin. Populations for the study are 62 sports personnel in the sports council Ilorin which comprised of Director of Sports, Stadium manager, organizing secretaries and coaches of the existing 20 sports in the Kwara State Sports Council. Researcher questionnaire designed in a modified four points likert rating scale was used to collect data from the respondents which was validated by a Professor of sports management and a season sports administrator, ministry of youth and sports, Abuja and tested for reliability using split half method and Cronbach alpha was used to determine the result with a coefficient of 0.80 obtained. Inferential statistic of multiple regressions was used to test the null hypotheses formulated at 0.05 level of significance. The findings reveal that leadership styles of sports administrators have significant relationship with organization performance, each leadership style has significant contribution to organization performance and all the leadership styles significantly contributed to organization performance. Among the recommendations suggested include: Sports administrators must be able to employ variety of leadership style is the best among others.
\end{abstract}

How To Cite:

Ajeigbe, I. Y, Owolabi, A. Y. \& Alansinsin, S. (21). Relationship Between Leadership Styles of Sports Administrators and Orgranisational Development in Ilorin Metropolis. Indonesian Journal of Sport Management, 1(1), 11-19. https://doi.org/10.31949/ijsm.v1i1.933

Email: issa.ajeigbe@kwasu.edu.ng 


\section{INTRODUCTION}

One of the basic and most important needs in an organization is leadership which is often considered as the solution to most important needs in an organization experience (Daft \& Marcic, 2006). Kent and Chelladurai (2001) avowed that leadership is an important determinant in the effective functioning of an organization. Drucker (2003) affirms that the manner in which a leader interacts with subordinates in an organization determines how well they perform. Among the human resources which occupy leadership positions in a sports organization are coaches and sport administrators such as director of sports, stadium manager and organization secretaries' e.t.c. Leadership has been defined as the process of an individual influencing the activities of an organized group towards goal achievement (Northouse, 2010). Leadership is also defined as the process goal of influencing the activities of organized group towards goal achievement. This individual would influence the activities of the sport department towards the goals of athletic success and economic viability all within the unique atmosphere in academia (Dexter \& Davis, 2002).

Naidoo (2007) expressed that sport a dministrator in an organization is required to demonstrate effective leadership qualities to manage the subordinate in the sports department. Dexter and Davis (2002) suggest that, the sports administrator can influence the activities of the sports department towards the goals of athletic success and economic viability. The relevance of effective leadership is high for skill-related, excellent-related, sustenance-related and curative-related service organizations in sport and physical activity (Chelladurai, 1999). The sports leaders are responsible for empowering subordinates to establish and achieve personal and organizational goals. Therefore, the degree of their leadership skills will largely dictate their actions with subordinates (Herrera \& Lim, 2003) citing (Naidoo, Coopoo \& Surujjlal, 2015). Effective leadership is considered a significant determinant of managerial effectiveness in any organization context (Doherty \& Danylchuk, 1996).

There is no one leadership style that is the best for staff effectiveness and development of the organization, therefore, a leader must use as many leadership styles as possible to foster organization development. Leadership style refers to a leader's behavior. Esere (2005) stated that a leader in an organization is an embodiment of a force that directs the entire organization towards the realization of the organizational goals. For instance, a sport administrator will ensure that staff work diligently to achieve the success in the organization, coaches would ensure that players come's for regular trainings so as to acquire and perfect skills that will enhance their better performance. However, there are different types of leadership styles that can be used by sports administrators to ensure optimal performance of staff in an organization that will facilitate organization development.

Authoritarian Leader: Under this leadership style all decision-making power are centralized in the leader. Such leader does not entertain any suggestion or initiative from subordinates (Kurt, 2009). An autocratic leader is otherwise known as hard-boiled, dictator as well as a domineering leader who uses his/her power to enforce rigid discipline on the staff. Ladani (2007) described authoritarian leader as a leader who strongly believes in strict compliance and obedience to command in the authority without considering the opinion of the staff under him. Kurt (2009) 
affirms that autocratic management have been successful as it provides strong motivation to the administrator. It also, permit quick decision-making as only one person decides for the whole group and keep each decision to themselves until they feel it is needed by the rest of the group.

Participative Leader: is otherwise known as a consultative or democratic leader. The participative leadership style favours' decision making by the group. Such a leader gives instruction after consulting the group. Kurt (2009) affirms that the decision of a participative leader is not unilateral as with the authoritarian leader because they arise from consultation with the group members and participation by them. A consultative leader encourages group participation in decision-making. He believes in people and communicates that belief (Clark, 2009).

Lassez-faire Leader: is described as the avoidance or absence of leadership (Judge \& Piccolo, 2004). This type of leadership approach, the leader surrenders or disclaim responsibilities and refused making decisions (Robbin, Judge \& Sanghi, 2007; Limsila \& Ogunlana, 2008). Kurt (2009) described Laissez-faire type of leadership as the type of leadership that is used to minimize the leaders' involvement in decision making, and hence allowing people to make their own decision. This type of leadership style is otherwise known as free rein. A free rein leader does not lead but leaves the group entirely to itself. This leadership approach is the most passive and ineffective form of leadership.

Transactional Leader: This type of leader offers a cognitive framework which helps to explain the willingness of an administrator to embrace a methodology of working with subordinates in purely a contractual manner (Case, 1998) as cited by (Ajeigbe,2015). In this type of leadership style, leaders would set expectations, goals and provide recognition and rewards when a task is completed (Goethals, Sorenson \& Burns, 2004). Transactional leader may be regarded as a reward-driven behavior wherein the subordinate behaves in such a manner as to elicit rewards or support from the leader (Field \& Herold, 1997; Hsu, Bell \& Cheng, 2002). There is great emphasis on the exchange, conditions and rewards associated with the fulfillment of requirements as stipulated by the leader (Bass \& Avolio, 1994). Jung, Wu and Chow (2008) posit that the contractual is the motivating factor that drives individuals towards the achievement of task set out for them. For example, with regard to sport administrators this may mean offering incentives or rewards to get teams or individuals to qualify, to compete or to win in high level competitions.

Transformational Leader: This leadership style involves a process of aligning subordinates' commitment to the organization's objectives and inspiring them to exceed their expected performance to achieve the organization's goals (Sivanathan \& Fekken, 2002; Pihie, Sadeghi \& Elias, 2011). Burns (1978) and Ingrid (2006) affirms that a transformational leader motivates his team to be effective and efficient. Communication is the base for goal achievement focusing the group on the final desire outcome or goal attainment. This leader is highly visible and uses chain of command to get the job done. The leader is always looking for ideas that move the organization to reach their vision. In this type of leadership approach, employers' or subordinates' intrinsic motivation and personal development is emphasized. Dexter and Davis (2002) argue that transformational leadership is the key to the continued success of organizations, because it promotes team cohesion and organization commitment. Armstrong (2001) laid out four main characteristics of 
transformational leadership which include: ethical behavior, shared vision, shared goals and leadership by example. Transformational leadership style is described as behavior that transcends the need for rewards and appeals to the higher-order needs of employees or subordinates, inspiring them to act in the best interest of the organization rather in their own self-interest (Bass, 1998; Northouse, 2010). According to Pierce and Newstrom (2008), transformational leaders use their personal values, vision, commitment to a mission, and passion to energize and move others towards accomplishment of organizational goals.

Organizational development is a technique used for bringing change in the entire aspect of the organization, rather than focusing attention on the individuals so that change is readily absorbed. According to French and Bell (n.d.), organizational development is a long-range effort to improve an organization's problem-solving and renewal processes particularly, through a more effective and collaborative management of organization culture with special emphasis on the culture of formal work teams with the assistance of a change agent or catalyst and the use of the theory and technology of applied behavior science (m.embrary.net).

Researchers at the University of Oxford found that the leaders can be effective change-agents within their own organizations if they strongly committed to "knowledge leadership" targeted towards organizational development. In their three-year study of UK healthcare organizations, the researchers identified three different mechanisms through which knowledge leaders actively "transposed", "appropriated" or "contended" change concepts, effectively translating and embedding these in organization practice. The objective of organizations development is to improve the organizations capacity to handle its internal and external functioning and relationships. This includes improved interpersonal and group processes, more effective communication, and enhanced ability to cope with organization problems of all kinds. It also involves more effective decision processes, more appropriate leadership styles, improved skill in dealing with destructive conflict, as well as developing improved levels of trust and cooperation among organizational members. Organizational development is aimed at organizational effectiveness. It therefore, has a number of outcomes. These can differ between organizations, but usually, they do include financial performance, customer satisfaction, organizational member engagement, and an increased capacity to adapt and renew the organization.

\section{METHOD}

The research design adopted in this study was a descriptive survey design of correlation type. This design became necessary as the study tried to find out the relationship between leadership styles of sports administrators and organization development in the sports council Ilorin. The target population for the study is the director of sports, stadium manager, organizing secretaries and coaches of existing twenty sports in the state sports council totaling 62 . No sample is selected as the researcher made use of all the 62 personnel as respondents for the study.

The researcher developed as structured questionnaire targed relationship between leadership styles of sports administrator and organization development (RBLSSAOD) to elicit pertinent information from the respondents. A section in the questionnaire requested demographic information of the participants. Two 
research questions and hypotheses were generated for the study and the hypotheses were tested using linear regression to determine the relationship between the independent and dependent variables in hypothesis one and to bring out the relative contribution each leadership style to organization development. All hypotheses were tested at 0.05 level of significant.

\section{RESULT AND DISCUSSION}

Relationship between the predictor variables (Authoritarian, Participative, Laissezfaire, transactional and transformational leadership styles) and the criterion variable (Organization performance). There was significant and positive relationship between leadership styles of sports administrators and organization performance (Autoritarian $[\mathrm{r}=.695, \mathrm{P}<0.05]$, participative $[\mathrm{r}=.709, \mathrm{P}<.05]$, laissezfaire $[\mathrm{r}=.696, \mathrm{P}<.05]$, Transactional $[\mathrm{r}=.535, \mathrm{P}<.05]$, Transformational $[\mathrm{r}=.606$, $\mathrm{P}<0.05])$.

Table 1: Table showing the relationship between leadership styles of sports administrators and

\begin{tabular}{lccccccc|}
\hline \multicolumn{1}{c}{ Variables } & $\begin{array}{c}\text { Perfor } \\
\text { mance }\end{array}$ & $\begin{array}{c}\text { Authorit } \\
\text { arian }\end{array}$ & $\begin{array}{c}\text { Participa } \\
\text { tive }\end{array}$ & $\begin{array}{c}\text { Laissez } \\
\text {-faire }\end{array}$ & $\begin{array}{c}\text { Transacti } \\
\text { onal }\end{array}$ & $\begin{array}{c}\text { Transform } \\
\text { ation }\end{array}$ & Sig \\
\hline Performance & 1.000 & .695 & .709 & .696 & .535 & .606 & \\
\hline Authoritarian & .695 & 1.000 & .719 & .501 & .726 & .882 & .000 \\
\hline Participative & .709 & .719 & 1.000 & .624 & .892 & .739 & .000 \\
\hline Laissez-faire & .696 & .501 & .624 & 1.000 & .539 & .462 & .000 \\
\hline Transactional & .535 & .726 & .892 & .539 & 1.000 & .870 & .000 \\
Transformatio & .606 & .882 & .739 & .462 & .870 & 1.000 & .000 \\
n & & & & & & & \\
Mean & 22.97 & 16.19 & 15.60 & 14.44 & 16.10 & 16.69 & \\
\hline SD & 3.98 & 2.974 & 2.62 & 2.88 & 2.60 & 2.47 & \\
\hline
\end{tabular}

Table 2 shows the relative contribution of each leadership style of sports administrators to the prediction of organization performance. Authoritarian $(\beta=.041, P>.05)$, Participative $(\beta=.990, P<.05)$, Laissez-faire $(\beta=.377, P<.05)$, Transactional $(\beta=-1.192, P<.05)$ and Transformational $(\beta=.702, P<.05)$. This indicates that while participative, laissez-faire, transactional and transformational were significant in their relative contribution to the prediction of organization performance, authoritarian leadership style was not.

Table2: The table showing the relative contribution of each leadership style of sports administrators to the prediction of organization performance.

\begin{tabular}{|c|c|c|c|c|c|}
\hline Model & $\begin{array}{c}\text { Unstandardized } \\
\text { coefficient }\end{array}$ & $\begin{array}{c}\text { Standardized } \\
\text { coefficient }\end{array}$ & $\mathrm{t}$ & Sig & Ranking \\
\hline & B std.error & $\beta$ & & & \\
\hline (Constant) & 1.530 & 1.890 & & .809 & .422 \\
\hline Authoritarian & .055 & .215 & .041 & .256 & .799 \\
\hline Participative & 1.504 & .263 & .990 & 5.717 & .000 \\
\hline Laisser-Fair & .521 & .112 & .377 & 4.650 & .000 \\
\hline Transactional & -1.825 & .346 & -1.192 & $\begin{array}{c}- \\
5.270\end{array}$ & .000 \\
\hline Transformational & 1.134 & .356 & .702 & 3.184 & .002 \\
\hline
\end{tabular}


Table 3: Table showing the composite contribution of leadership styles of sports administrators to the prediction of organization performance

\begin{tabular}{cccccc}
\hline Df & Model & Sum of square & Mean square & F & Sig \\
\hline 5 & Regression & 755.148 & 151.030 & 39.747 & .000 \\
56 & Residual & 212.787 & 3.800 & & \\
61 & Total & 967.935 & & & \\
\hline $\mathrm{R}=.883$ & R2 $=.780^{*}$ & Adj. R2 $=.761^{*}$ & & &
\end{tabular}

It is shown in table 3 that the leadership styles were significant in their composite contributions to the prediction of organization performance $(F(5,56)$ $=39.747, \mathrm{R}=.883, \mathrm{R} 2=.780, \mathrm{Adj} . \mathrm{R} 2=.761$ ). About $78 \%$ of the variation in organization performance was accounted for by the predictor variables.

The Result of hypothesis one (Ho1) shows a significant and positive relationship between leadership styles of sports administrator and organization performance corroborates with the submission of Daft and Marcic (2006) who affirms that leadership styles of administrators is one of basic and most important needs in an organization that can enhance better performance of subordinate. Kent and Chelladurai (2001) avowes that leadership is an important determinant in the effective functioning of an organization. Naidoo (2007) Express the view that sports administrator in an organization is required to demonstrate effective leadership qualities to manage the subordinates for better performance.

The sports administrators are responsible for empowering subordinates in an organization to establish and achieve personal organization goals. Therefore, the degree of their leadership skills will largely dictate their actions with subordinates (Herrera \& Lim, 2003) citing (Naidoo, Coopo \& Surujlal, 2015). Therefore, effectiveness in any organizational context (Doherty \& Danylchuk, 1996). There is no one leadership style that is the best for staff effectiveness and development of the organization, therefore, a leader must use as many leadership styles as possible to foster organization development. Drucker (2003) affirms that the manner in which a leader or administrator interacts with subordinates in an organization determines how well they perform.

The Result of hypothesis two (Ho2) indicates that participative, laissez-faire, Transactional and Transformational leadership style were significant in their relative contribution to the prediction of organization performance while authoritarian leadership style was not. This finding corroborates the finding of Murray (2002) when he stated that when participative leadership style is employed in an organization, the staff are always more committed to actions social commitment to one another in enhanced and commitment to put in their best for better performance is enhanced. Also, When Laizzez-faire approach is employed by administrator by encouraging the subordinate well they will initiate new things and they will be more creative in their thinking which may improve organization performance (Kurt, 2009). In addition, Transactional leader may be regarded as a reward-driven behavior where in the subordinate behaves in such a manner as to elicit rewards or support from the leader (field \& Herold, 1977, Hsu, Bell \& Cheng, 2002). Jung, $\mathrm{Wu}$ and Chow (2008) Posit that the contractual agreement in the motivating factor that drives individuals towards the achievement of task set out for them. For example, with regards to sport administrators this may mean offering incentives or rewards to get teams or individuals to qualify, to compete or to win in. 
Transformation leader is a leadership style that involves a process of aligning sub-ordinates commitment to the organization's objectives and inspiring them to exceed their expected performance to achieve the organization's goals (Sivanathana \& Fiekken, 2002, pihie, sadeghi \& Elias, 2011). Ingrid (2006) affirms that a transformational leader motivates subordinates to be effective and efficient $o$ as to improve their performance in the organization. Finally, the result of hypothesis three (HO3) equally reveals that the leadership styles were significant in their composite contributions to the prediction of organization performance. This implies that all the leadership styles addressed in this study contributes to organization performance. This finding is in-line with the submission of Naidoo (2007) who expressed that the sport administrator in an organization is required to demonstrate effective leadership qualities to manage the subordinate in the organization. Esere (2005) stated that a leader in an organization using different leadership approach towards the realization of organization goals.

\section{CONCLUSION}

It was concluded that there was significant positive relationship between leadership styles of sports administrator and organization performance, it was also concluded that participative, Laissez-faire, Transactional and transformational leadership styles were significant in their authoritarian leadership style was not. It was also concluded that leadership styles were significant in their composite contribution to the prediction of organization performance. The following recommendations were suggested based on the findings of study. The Sports administrator must employ variety of leadership styles to enhance subordinate performance in organization based on the belief that no single leadership style is the best. The Sports administrator must be conversant with the use of participative, Laissez-faire, transactional and transformational leadership styles on dealing with subordinates in the organization as they are found to be predictor of organization performance. Sports administrator should employ the use incentives and rewards to encourage good performance of staff so as to enhance their further commitment to duty that will bring about achievement of organization goals.

\section{ACKNOWLEDGEMENT}

Thanks to the Sports Director, Stadium Manager, Organizing Secretary and Coaches who helped complete this research.

\section{REFERENCES}

Ajeigbe, Y.I. (2015). Coaches Leadership Styles as Predictors of Athletes Performance in Nigeria Colleges of Education Games. America Strategic Leadership Journal. 1(2) 1-21.

Arstrong, S. (2001). Are you a transformational coach? Journal of physical Education, Recreation and Dance 72(3), 44-47

Bass, B. \& Avolio, B. (1995). MLQ Multifactor Leadership Questionnaire. Redwood city, C.A: Mind Garden.

Case, R. (1998). Leadership Member Exchange Theory and Sport: Possible Applications. Journal of Sport Behavior 21 (4) 387-392 
Chelladurai, P. (1999). Human Resources Management in Sports and Recreation II. Champaign Illinois: Human Kinetics

Clark, D. (2005). Concepts of leadership. http://www.nwlink.com retrieved from the internet $12^{\text {th }}$ nmay, 2005.

Daft, R.L. \& Marcic, C. (2006). Understanding Management (5 $5^{\text {th }}$ ed.). Mason. OH: Thomson Higher Education.

Dexter, J. \& Davis, D.J. (2002). An Analysis of Perceived Leadership Styles and Levels of Satisfaction of Selected Junior College Athletic Directors and Head Coaches. The Sport Journal 23(2), 22-27.

Doherty, A.J. \& Darrylchuk, K.E. (1996). Transformational and Transactional Leadership in Intervarsity Athletics Management. Journal of Sport Management, 10(3), 45-49

Drucker, P.F. (2003). On the Profession of Management. Boston: Harvard Business school Press.

Esere, M.O. (2005). Leadership Styles of Husbands in Homes: Implications for Family Stability. The Nigerian Journal of Guidance and Counseling. Department of counselor Education, Faculty of education, University of Ilorin, Nigeria.

Fields, D. \& Herold, D. (1997). Using the Leadership Practices Inventory to Measure Transformational and Transactional Leadership

Hsu, C.H., Bell, R.C. \& Cheng, K.K. (2002). Transformational Leadership and Organizational Effectiveness in Recreational Sport/Fitness Programs. The Sport Journal, (2), 1-7.

Ingrid, B. (2006). Facilitating to Lead. Jossey-Bass.

Judge, T.A. \& Piccolo, R.F. (2004). Transformational Transactional Leadership: A MetaAnalytic Test of their Relative Validity. Journal of Applied Psychology, 89(5), 755-768.

Jung, D., Wu, A. \& Chow, C.W (2008). Towards Understanding the Direct and Indirect Effects of Transformational Leadership on Firm Innovation. The leadership Quarterly, 19,582-594.

Kent, A.\& Chelladurai, P. (2001). Perceived Transformational Leadership, Organizational Commitment and Citizenship Behavior: A Case Study in Inter Collegiate Athletics. Journal of Sport Management, 15, 135-159

Kurt, L. (2009). Leadership Styles. www.legecee.com/leadership/leadership styles.html55k-cached-similar pages. Retrieved 30th September, 2009.

Ladani, B.A. (2007). An Introduction to Sports Management. Kaduna: Sunjo A.J. Global Links Ltd.

Linsila, K.\& Ogunlana, S.O. (2008). Performance and Leadership Outcome Correlates of Leadership Styles and Sub-Ordinates Commitment. Engineering, construction and Architectural Management 15(2), 164-184.

Murray, J. (2002). Understanding the Many Different Types of Leadership Styles is Necessary First Step in Leadership Development.

Naidoo, P. (2007). An Analysis of Perceived Leadership Styles and Levels of Job Satisfaction of Sport Administrators Employed at Tertiary Institutions in South Africa. Unpublished Doctoral Thesis, Durban: University of Kwazulu-Natal.

Naidoo, P., Coopoo, Y. \& Surujlal, J. (2015). Perceived Leadership Styles of Sports Administrator and the Relationship with Organizational Effectiveness. African Journal 
for Physical, Health Education, Recreation and Dance, November (Supplement 1), 167181.

Northhouse, P.G. (2010). Leadership-Theory and Practice ( $5^{\text {th }}$ ed.). Thousand Oaks, CA: Sage.

Pihie, Z.A.L., Sadeghi, A. \& Elias, H. (2011). Analysis of Head of Departments' Leadership Style: Implication for Improving Research University Management Practices, Procedia-Social and Behavioral Sciences, 29, 1081-1090.

Robbins, S.P., Judge, T.A. \& Sanghi, S. (2007). Organization Behaviour (12 th ed.). New Delhi, India: Pearson Prentice Hall.

Sivanathan, N. \& Fekken, G.C. (2002). Emotional Intelligence, Moral Reasoning and Transformational Leadership. Leadership and Organization Development Journal, 23(3/4), 198-204.

\section{Copyright holder:}

(C)(2021) Issa Yaqub Ajeigbe, Abdulraheem Yunus Owolabi, Semiu Alasinrin

First publication right:

Indonesian Journal of Sport Management

This article is licensed under: 